\title{
THE EFFECT OF DENSITY AND FLOOR TYPES ON PERFORMANCE, PHYSIOLOGICAL STATE AND IMMUNE RESPONSE OF BROILERS
}

\author{
D. Sunarti ${ }^{1}$ Haryono $^{2}$ and Soedarsono ${ }^{1}$ \\ ${ }^{1}$ Faculty of Animal Agriculture, Diponegoro University, \\ Tembalang Campus, Semarang 50275 - Indonesia \\ ${ }^{2}$ Livestock and Animal Health Office of Central Java, \\ Tarubudaya-Ungaran, Central Java - Indonesia \\ Corresponding E-mail: dwisunarti@gmail.com
}

Received October 12, 2010; Accepted November 28, 2010

\begin{abstract}
The purpose of this research was to study the effect of density and floor types on performance, physiological state and immune response of broilers. The research involved 368 male broilers of the New Lohman strain aged 8 days which were raised up to 35 days at different densities and floor types. Floor types consisted of rice hull litter and bamboo slat were used as the main plot; while densities of 7 , 10,13 and 16 birds $/ \mathrm{m}^{2}$ applied as the sub-plot. The results showed that the final body weight gain of the 35-day Lohmann broilers at densities of 7,10 and $13 \mathrm{birds} / \mathrm{m}^{2}$ were $28.22,24.43$ and $19.27 \mathrm{~kg}$ respectively, compared to $16 \mathrm{birds} / \mathrm{m}^{2}$ at $13.53 \mathrm{~kg}(\mathrm{P}>0.05)$. Broilers in the bamboo slats floor had lymph weight at $3.73 \mathrm{~g}$ compared to the litter floor at $2.55 \mathrm{~g}(\mathrm{P}<0.05)$. Also, broilers in the bamboo slats had average RHL (0.65) lower than broilers in the litter floor (0.79). It could be concluded that bamboo slats best being used for broilers up to a density of 13 broilers $/ \mathrm{m}^{2}$.
\end{abstract}

Keywords: broilers, density and floor types, physiological state, immunity response

\section{INTRODUCTION}

Genetically broilers have a high growth rate, good feed conversion resulting in a large body weight. Within a relatively short period, broilers can be harvested at 5-6 weeks of age, with body weights ranging from 1.5 to $2.0 \mathrm{~kg}$ Raising broilers with optimum body weights is largely determined by genetic factors, and environmental factors such as comfortable housing conditions, feed and good practices. The dominant environmental factors for optimum production include nutrition, temperature, humidity, air circulation, density, floor types and lighting (Borges et al., 2004; Sunarti, 2004).

Increased temperature in hot-climate regions has a negative impact on broiler health and performance. Stress involves heat exchange between birds and its environment, which in the process involves the heat production mechanism, adjustment of body fluid, hormones, blood circulation, breathing and metabolism under stress and feed consumption. Heat stress will induce a cascade reaction on the nervous system and endocrine, resulting in increased activity in the hypothalamus-hypofisa-adrenal tract.
Density will impact broiler performance, reduced feed intake due to increased temperature, spilled feed and reduced opportunity to feed. Increased density will also reduce growth, feed efficiency, increased mortality, increased cannibalism, and high shows of breast blisters, poor feather growth and broken bones while processing. Ideal density is suggested 10-12 broiler $/ \mathrm{m}^{2}$, and especially for lowlands it is suggested at $8-10$ broiler $/ \mathrm{m}^{2}$ (Kartasudjana and Suprijatna, 2006).

Broilers in high densities do not only react in performance, but also physiological indicator. Gross and Siegel (1983) states that the primary hematological response, is the change in Heterophyl-Limphocyte Ratio (RHL) of the blood leucocytes.

Heterophyl-Lymphocytes ratio have been widely accepted confidently as a physiological indicator towards stress responses on chickens (Gross and Siegel, 1983) and has always been used as an indicator to identify the presence of chronic stress (Scope et al., 2001).

Observing immunity and antibody response towards antigens given to poultry is generally done by measuring the spleen weight, bursa 
fabricious and thymus (Pope, 1991; Gross and Siegel, 1990; Scott et al, 1994). Antibody is an effect of the humoral immunity response, interacting specifically towards antigen. On chickens, there are three antibody (immunoglobulin) molecule classes, which are $\operatorname{IgM}, \operatorname{IgG}(\operatorname{IgY})$ and $\operatorname{IgA}$ (Gisela, 1997). Squires (2003) explains that antibody titter formed after the primary ND vaccination is not yet optimum, and that the antibody ND formed on the secondary response is higher.

Broilers in Indonesia are generally bred on litter-floored and slat-floored. The two floor types have their own advantages and disadvantages. The slat floors are chosen by farmers in lower lands during the summer; as the litter floors are more sensitive to the high humidity causing it to be damp and unsuitable for use. Farmers have not yet fully understood the impact of choosing the most appropriate floor types on broilers. This research was conducted to examine the effect of density and floor types on performance, physiological state and immune response of broilers.

\section{MATERIALS AND METHODS}

A number of 368 8-days-old male broiler of the New Lohmann strain were used as an experimental animals. Animals were fed by commercial mash-type starter feed (Comfeed Broiler-I SP) for the d-1 to d-21; and a pellet-type finisher (Comfeed Broiler-II) for d-22 onwards. The nutrition content is presented in Table 1.

Broilers used in the experiment were raised in a staged housing, elevated $200 \mathrm{~cm}$ high from ground level, with $12 \mathrm{~m}$ in length, $6 \mathrm{~m}$ in width and $3 \mathrm{~m}$ high. The wall was made of bamboo halves; the lower part of the wall, as high as $1 \mathrm{~m}$; the halves were densely tied together to fence, and the remaining $2 \mathrm{~m}$ of the height the halves were scarcely tied together. A plastic curtain was placed around the wall. The roof of the broiler housing was made of clay. The broiler housing was then subdivided into 32 rectangular-shaped experimental housing, each of which was $1 \mathrm{~m}^{2}$ in area and separated with a $50 \mathrm{~cm}$ high wire-wall. There were 8 rows, each row contains 4 housing. 4 rows were set up for rice hull litter floor; and the remaining 4 rows were for bamboo-slat floored. Each experimental housing was equipped with 1 feed container, 1 drinking fountain, 140 Watt light bulb with a reflector and a thermometer. A hygrometer and a clock were mounted on the wall.
The 1- to 7-day old chicks were placed in the rice hull litter floor, and on the $\mathrm{d}-8$, the chicks were randomly moved to the 32 pen, with different densities $\left(7,10,13\right.$ and 16) birds/ $\mathrm{m}^{2}$ on the bamboo slat floor and rice hull litter floor with 4 replication. Broiler chicks were then reared until 35 days age.

The 4-day old chicks were vaccinated with ND active strain B-1 eye drops; and on the d-14 were vaccinated with Infectious Bursal Disease (Gumboro) diluted in the drinking water. On the d-21, chicks were vaccinated with ND active strain La Sota diluted in the drinking water. Broilers were harvested on the d-35 where they were then weighed, cut and measured for parameters.

Parameters observed in the experiment were the following: (1) Performance, shown by body weight, feed consumption, feed conversion ratio and carcass weight; (2) Physiological state, shown by the heterophyl-lymphocite ratio, Lymph weight, and bursa fabrisius weight; (3) Immune response, shown by the antibody titter of Newcasle Disease (ND); (4) Number of oocyst Eimeria sp.

\section{Statistical Analysis}

The data obtained was analyzed using the analysis of variance $\mathrm{F}$ type, with significant level $5 \%$. If there was an effect from treatments then a Duncan test was applied, using the Statistical Analysis System (SAS) 6.12 for Windows software to distinguish the effect of each treatment. For the oocyst Eimeria $\mathrm{sp}$ data was analyzed using the non-parametric Kruskal Wallis test with the SPSS software.

\section{RESULTS AND DISCUSSION}

\section{Environmental Condition}

The environmental microclimate condition of the experiment coop shows that the average daily temperature was $28.43 \pm 0.82{ }^{\circ} \mathrm{C}$ with an average humidity of $72.15 \pm 9.50 \%$. In the slat floored housing, the average temperature was $28.39 \pm 0.83^{\circ} \mathrm{C}$, and in the litter floored housing it was $28.47 \pm 0.88{ }^{\circ} \mathrm{C}$. The day temperature in the slat floored coop was $31.68 \pm 0.51{ }^{\circ} \mathrm{C}$ and in the litter floored coop it was $31 . \overline{7} 2 \pm 0.69{ }^{\circ} \mathrm{C}$. Average night temperature in the slat floored coop was $27.66 \pm 1.53{ }^{\circ} \mathrm{C}$ and in the litter floor it was $27.72+1.60{ }^{\circ} \mathrm{C}$.

The above conditions show a microclimate that was outside the comfort temperature zone of 
Table 1. Chemical Composition of Feed Used in the Experiment

\begin{tabular}{lcc}
\hline \multicolumn{1}{c}{ Nutrients $(100 \%$ dry matter) } & \multicolumn{2}{c}{ Chicken Feed } \\
\cline { 2 - 3 } Crude Protein (\%) & Comfeed Broiler-I SP & Comfeed Broiler-II SP \\
\hline Crude Fat (\%) & 24.49 & 22.89 \\
Crude Fiber (\%) & 4.91 & 5.25 \\
Water (\%) & 7.66 & 5.53 \\
Ash (\%) & 9.68 & 11.38 \\
Calcium (\%) & 6.38 & 4.96 \\
Phosphor (\%) & 2.35 & 2.48 \\
NFE (\%)* & 7.73 & 7.18 \\
Metabolic Energy (kcal/kg)* & 46.88 & 49.99 \\
* Calculation based on the Balton Formula (Siswohardjono, 1982) & 3,165 \\
ME = = 40.81 \{0.87 (Crude Protein+ 2.25 Crude Fat + ENN) + 2.5 $\}$ & \\
ENN = (100 - Water content - Ash content - Crude Protein - Fat and - Crude Fiber)
\end{tabular}

a bird's habitat, which was $15-25^{\circ} \mathrm{C}$ (El Boushy and Morle, 1978) and outside its optimum temperature or thermo neutral zone, which usually ranges $18-23{ }^{\circ} \mathrm{C}$ with humidity of $50-70 \%$ (Borges, 2004).

\section{Broiler Performance}

The result showed an increase in body weight of broilers from the first to the fourth week of age (28 days); $82.78 \mathrm{~g}$ (slat floor) and 78.07 (litter floor), but entering the fifth week or after the broiler was 35 day old, there was a decrease in body weight; $75.04 \mathrm{~g}$ (slat floor) and $66.12 \mathrm{~g}$ (litter floor).

The observation results for broiler performance such as body weight, daily body weight increments, feed consumption, feed conversion ratio (FCR) and carcass weight are shown in Table 2.

It can be seen in Table 2 that density has a significant effect $(\mathrm{P}<0.05)$ on the body weight and carcass weight; and has an insignificant effect on the daily body weight increments and feed conversion ratio (FCR). The results were then analyzed by Duncan test, and showed that densities of 7, 10 and 13 birds $/ \mathrm{m}^{2}$ produced higher body weight and carcass weight compared to densities of $16 \mathrm{birds} / \mathrm{m} 2$. Statistically, the body weight and carcass weight in the densities of 7,10 and 13 birds $/ \mathrm{m} 2$ have very little difference ( $>0.05$ ), while density of 16 birds/ $\mathrm{m} 2$ showed the lowest body and carcass weight. The final body weight of the 35-day-old male Lohmann broilers at densities of 7, 10, 13 and $16 \mathrm{birds} / \mathrm{m} 2$ were 13.53, 19.27, 24.43 and $28.22 \mathrm{~kg}$ respectively.

The densities of 7,10 and 13 birds/ $\mathrm{m}^{2}$ produced a good body weight performance score, while 16 birds/ $\mathrm{m} 2$ showed the opposite. Increasing the density up to 16 bids $/ \mathrm{m} 2$ at a microclimate with $28.43 \pm 0.86{ }^{\circ} \mathrm{C}$ in temperature and $72.15 \pm 9.5 \%$ in humidity has a negative effect on broiler performance as it resulted in lower final body weight and carcass weight. This may occured due to the limited space to move around freely and the increased competition for feed, and hence the unequal growth. Several researchers have concluded that high temperatures disrupt poultry's livelihood, reduces growth, feed intake, daily body weight and feed efficiency, feed digestion, egg production and egg weight (Mills et al, 1999); increases mortality and weakens the immune system (Naseem et al, 2005); affects performance, egg quality and immunity functions on commercial layer hens (Mashaly et al, 2004). It can be said that density of 13 birds/ $\mathrm{m} 2$ was the maximum limit that the the broiler housing can contain in order to obtain a good performance on broilers during the summer in a lowland area. Increasing the density to more than $13 \mathrm{birds} / \mathrm{m} 2$ or $24.43 \mathrm{~kg} / \mathrm{m} 2$ may result in poor performance and may not be in line with animal health and animal welfare principles

\section{Broiler Physiological State}

The result of the research towards 35 day old broiler's physiological state was observed from the Heterophyl-Lymphocyte Ratio (RHL), spleen weight and bursa fabrisius weight, shown in Table 3. 
Table 2. The Average Body Weight, Feed Consumption, Carcass Weight and Feed Conversion on 35 day old Broilers.

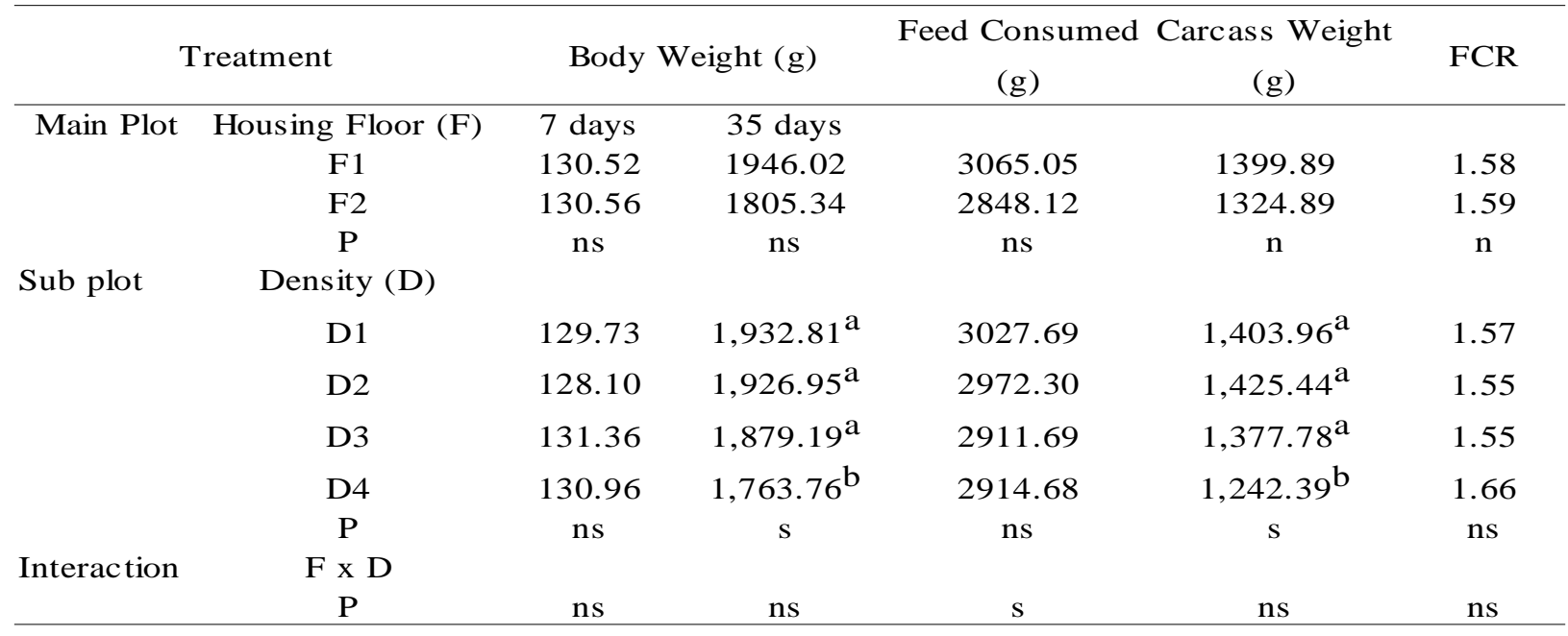

Average values with different superscripts on the same parameters shows significantly different $(\mathrm{P} \leq 0.05)$

Average values with the same superscript on the same parameters shows an non significant difference (P>0.05)

Numbers show average body weight (g), feed consumption (g), carcass weight (g) and feed convertion ration (FCR)

$\mathrm{s}=$ significantly different and $\mathrm{ns}=$ non significant

$\mathrm{F} 1=$ slat floor $; \mathrm{F} 2=$ rice hull littered floor $; \mathrm{FCR}=$ feed conversion ratio $; \mathrm{P}=$ Probability

$\mathrm{D} 1=$ density of $7 \mathrm{birds} / \mathrm{m}^{2} ; \mathrm{D} 2=$ density of $10 \mathrm{birds} / \mathrm{m}^{2} ; \mathrm{D} 3=$ density of $13 \mathrm{birds} / \mathrm{m}^{2} ; \mathrm{D} 4=\mathrm{density}$ of $16 \mathrm{birds} / \mathrm{m}^{2}$ );

D4 = density of $16 \mathrm{birds} / \mathrm{m}^{2}$

The results in Table 3 on physiological state shows that there was a significant effect $(\mathrm{P}<0.05)$ of floor types on spleen weight and has no significant effect $(p>0.05)$ on the Heterophyle Lymphocyte Ratio (RHL) and bursa fabrisius weight. Results also showed that density has no significant effect on RHL, spleen weight or bursa fabrisius weight.

Broilers in the bamboo slat floor has a significantly $(\mathrm{P}<0.05)$ higher lymph weight $(3.73$ g) compared to the ones in the litter floor $(2.55 \mathrm{~g})$, however the density does not have a significant effect $(p>0.05)$ on the lymph weight. Broilers in the bamboo slat floor have a similar fabrisius weight $(p>0.05)$ compared to the litter floor broilers. Density does not significantly influence $(\mathrm{P}>0.05)$ lymph weight.

The lymph weight and the bursa fabrisius weight on 35 day old bamboo slat broilers were higher than the litter floor broilers (see Table 3). Physiologically, lymph organ and the bursa fabrisius play a significant role in regulating the body immune system. Researchers have studied that the immune system was greatly affected by environmental stress that triggers the increased production of corticosteroid, and results in decreased body weight and atrophy of the lymph organs, tymus and bursa fabrisius (Gross and Siegel, 1981). Puvadolpirod et al, (2000) explained that environmental stress such as temperature, humidity and high content of ammonia will induce stress on broilers and result in decreased spleen weight (lymph, tymus and bursa fabrisius).

Slat floor broilers have a higher lymph weight and have a lower stress potential because the follicles in the lymph organ cortex do not go through atrophy, or there was no retraction in the lymphoid. This was different to the litter floor broilers with a lower lymph weight and has a higher stress potential because the follicles in the lymph organ cortex goes through atrophy or lymphoid retraction.

Litter floor broilers have a higher average RHL (0.72) compared to the slat floor broilers (0.65). This result shows that the slat floor broilers indicate high stress compared to the litter floor broilers. The RHL score was highly affected by the management, environmental factor, humidity, gas pollution $\left(\mathrm{CO} 2, \mathrm{CO}, \mathrm{NH}_{3}\right.$ and $\left.\mathrm{H}_{2} \mathrm{~S}\right)$, which were not easily controlled and induced different stress levels on broilers. The density of 
Table 3. Average Heterophyl - Lymphocyte Ratio, Lymph Weight and Bursa Fabrisius Weight on 35 day old Broilers

\begin{tabular}{|c|c|c|c|c|}
\hline \multicolumn{2}{|c|}{ Treatment } & \multirow{2}{*}{$\begin{array}{c}\text { Heterophyle- } \\
\text { Lymphocyte Ratio (HLR) } \\
\end{array}$} & \multirow[t]{2}{*}{ Lymph Weight (g) } & \multirow[t]{2}{*}{ Bursa Fabrisius Weight (g) } \\
\hline Main Plot & Housing Floor $(\mathrm{F})$ & & & \\
\hline & $\mathrm{F} 1$ & 0.65 & $3.73^{\mathrm{a}}$ & 1.55 \\
\hline & $\mathrm{F} 2$ & 0.72 & $2.55^{\mathrm{b}}$ & 1.03 \\
\hline & $\mathrm{P}$ & ns & $\mathrm{s}$ & ns \\
\hline \multirow[t]{6}{*}{ Sub Plot } & Density (D) & & & \\
\hline & D1 & 0.60 & 3.32 & 1.39 \\
\hline & D2 & 0.65 & 3.00 & 1.46 \\
\hline & D3 & 0.71 & 2.95 & 1.25 \\
\hline & D4 & 0.79 & 3.30 & 1.07 \\
\hline & $\mathrm{P}$ & ns & s & ns \\
\hline \multirow[t]{2}{*}{ Interaction } & FxD & & & \\
\hline & $\mathrm{P}$ & $\mathrm{ns}$ & $\mathrm{s}$ & ns \\
\hline
\end{tabular}

Average values with different superscripts on the same parameters, shows significant difference $(\mathrm{P} \leq 0.05)$

Average values with the same superscript on the same parameters, shows an non ignificant difference (P>0.05)

Numbers show average Heterophyle - Ly mphocy te Ratio (RHL), ly mph weight (g) and bursa fabrisius weight (g)

$\mathrm{s}=$ significant difference; $\mathrm{ns}=$ non significant difference $; \mathrm{P}=$ Probability .

$\mathrm{F} 1=$ bamboo slat floor, F2 = rice hull litter floor

$\mathrm{D} 1=$ density of $7 \mathrm{birds} / \mathrm{m}^{2} ; \mathrm{D} 2=$ density of $10 \mathrm{birds} / \mathrm{m}^{2} ; \mathrm{D} 3=$ density of $13 \mathrm{birds} / \mathrm{m}^{2} ; \mathrm{D} 4=$ density of $16 \mathrm{birds} / \mathrm{m}^{2}$

Table 4. Average Newcastle Disease Antibody

Titter on 35-day-old Broilers

\begin{tabular}{ccc}
\hline & Treatment & $\begin{array}{c}\text { ND Antibody } \\
\text { Titter (Log2) }\end{array}$ \\
\hline Main Plot & Floor Type & \\
& (F) & \\
& F1 & 2.97 \\
& F2 & 3.93 \\
Sub Plot & P & ns \\
& Density (D) & \\
& D1 & 3.63 \\
& D2 & 3.18 \\
& D3 & 3.54 \\
& D4 & 3.46 \\
Interaction (FxD) & P & ns \\
& P & ns \\
\hline
\end{tabular}

16 birds/ $\mathrm{m}^{2}$ with RHL value of (0.79) indicated high stress on broilers based on the stress indicators presented by Gross and Siegel (1993), which were 0.2 (low); 0.5 (optimum) and 0.8 (high).

This research showed that the increasing
RHL value was parallel to the increased stress level and to the increased density. The increased RHL value on stressed broilers is related to the increased production of glucocorticoid. The presence of the glucocorticoid receptor in the defense cells will disrupt the B-cell function in the regulation of immune cells production. The change in gene expression mediated by the glucocorticoid can disrupt the production of immune cells (Padgett and Glasser, 2003). RHL values were always used as stress indicator (heat stress) on poultry due to the strong relations between the discharge of glucocorticoid and the formation of leucocyte cell, especially Heterophyl and Lymphocyte (Boonstra, 2005). The increased RHL value was a response to a low to medium stress level, and if followed by the increased basophile, then it indicates high stress (Maxwell et al, 1992; Maxwell, 1993). Broilers enduring chronic heat stress will experience a decrease in the number of lymphocyte and an increased number of Heterophyl, and an increased RHL value (Aengwanich and Chinrasri, 2003).

\section{Broiler Immunity Response}

The research evaluates the broiler immunity response using the Newcastle Disease (ND) 
Table 5. Average Score of Oocyst Eimeria sp on 35 Day Old Broilers

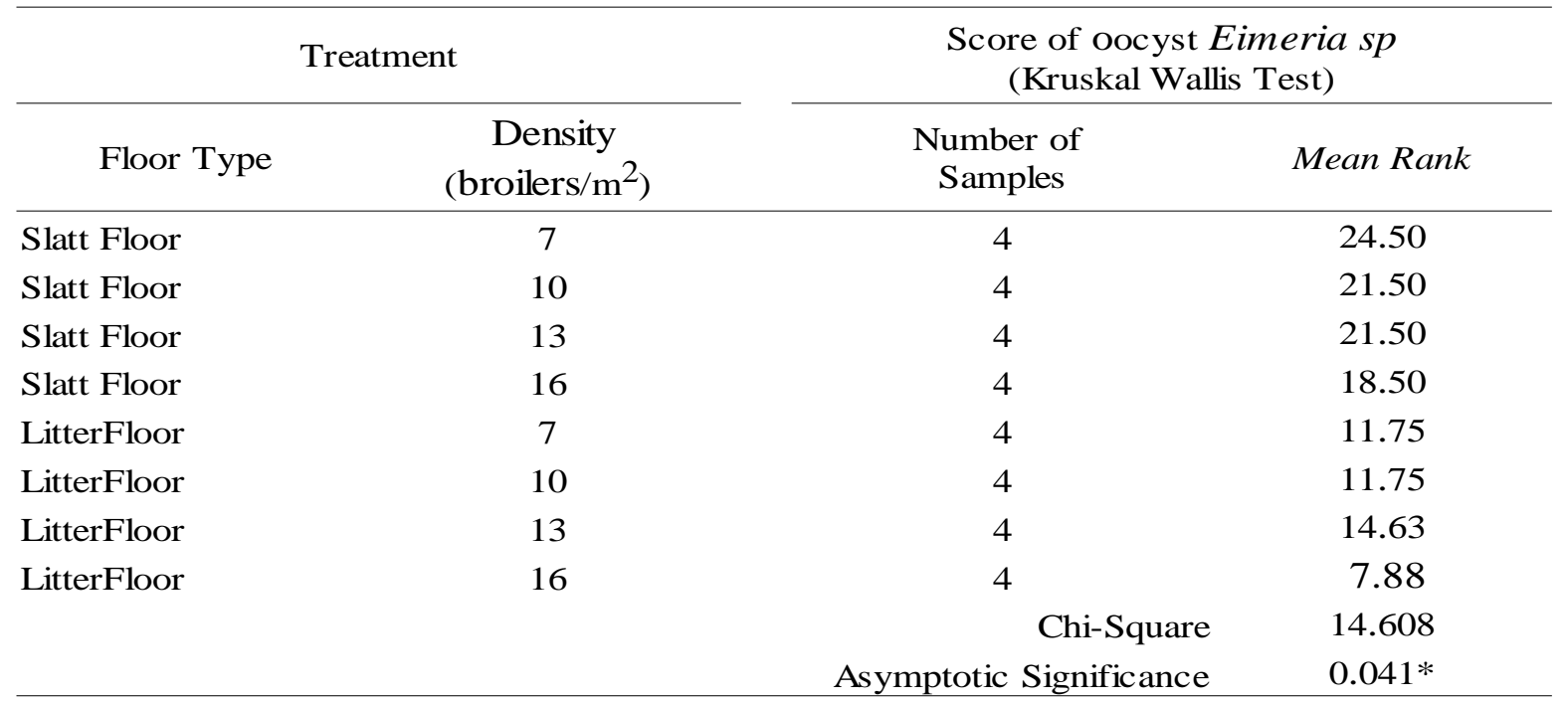

Mean rank is obtained from an average score of the oocyst Eimeria sp, : 5 is for zero oocy st or none can be seen from under the microscope; 4 is for oocyst of $1-1000 ; 3$ is for oocyst of $1001-3000 ; 2$ is for oocyst of $3001-$ 5000 ; and 1 is for oocyst of greater than 5000 to infinity

Data is processed with the Kruskal Wallis on SPSS

* There is significant difference on the average score at 8 different treatments $(\mathrm{P} \leq 0.05)$

antibody titter as a parameter. Results post vaccination after 35 days are shown in Table 4.

The experiment on immunity response system in Table 4 shows that floor types, both rice hull litter and bamboo slat do not have a significant effect $(\mathrm{P}>0.05)$ on the ND antibody titter. The average ND antibody titter on slat floor broilers was $(\log 2) 2.97$ and on the litter floor broilers $(\log 2)$ 3.93. Average titter on different densities for $7,10,13$ and 16 chicks/ $\mathrm{m}^{2}$ are $(\log 2)$ $3.63,3.54,3.46$, respectively.

Results to the serology test HI-ND determined that the ND antibody titter on 35 day old broilers (14 days post vaccination of the ND La Sota via drinking water on 21 day old chicks), showed a low ND antibody titter of (log2) 2.97 on slat floor and 3.94 on litter floor. This was because a booster was not applied to the ND vaccination, considering that 35 days was the harvesting age. The antibody titter formed was a primary response towards the ND vaccination; therefore the titter was not yet optimum.

\section{Oocyst Eimeria sp Infection}

The number of oocyst Eimeria $s p$ obtained under the microscope was scored based on the degree of coccidiosis infection. One oocyst in a colon was counted as an infection, as one oocyst was capable of producing 4 sporocyst and each sporocyst can produce 2 sporozoit.

The average score for oocyst Emeria sp on 35 day old broilers is shown in Table 5. Statistical analysis on the score of oocyst Eimeria sp (Table 5) shows that there was a significant effect $(\mathrm{P}<0.05)$ of density on the number of oocyst Eimeria sp. On slat floor with densities of 7, 10, 13 and 16 birds/ $\mathrm{m}^{2}$, the oocyst score is higher compared to the litter floor. This shows that slat floor broilers are less exposed to Eimeria $s p$ infection, compared to the litter floor broilers. Densities up to $13 \mathrm{birds} / \mathrm{m}^{2}$ on slat floorshows a higher oocyst score compared to the density of 16 birds/ $\mathrm{m} 2$, while litter floor broilers with densities of $7,10,13$ and 16 birds/ $\mathrm{m}^{2}$ shows a lower oocyst score. The results showed that rice hull litter floors are potential producers of oocyst Eimeria $s p$; with the increased density, litter floors tended to show an increased production of oocyst Eimeria sp, and hence the low score.

\section{CONCLUSION}

It can be concluded that the best weight gain demonstrated at bamboo slat floor at density 13 birds $/ \mathrm{m}^{2}$, produced $24.43 \mathrm{~kg} / \mathrm{m}^{2}$ broiler at individual weight of $1.932 \mathrm{~kg}$ and $1.425 \mathrm{~kg}$ carcass. 


\section{REFERENCES}

Aengwanich, W. and O. Chinrasri. 2003. Effect of chronic heat stress on red blood cell disorders in broiler chickens. Mahasarakham Univ. J. 21:1-10.

Borges, S.A., Fav Da Silva, A. Maiorka, D.M. Hooge and K.R.Cummings. 2004. Effects of diet and cyclic daily heat stress on electrolyte, nitrogen and water intake, excretion and retention by colostomized male broiler chickens. Int. J. Poultry Sci. 3: 313-321.

Boonstra, R. 2005. Coping with changing northern environments: the role of the stress axis in birds and mammals. Integr. Comp. Biol. 44:95-108

El Boushy, A.R and A.L. Van Morle. 1978. The effect of climate on poultry physiology in the tropic and their improvement. Wordl's Poult. Sci. 34:155-169.

Gross, W.B., and P. B. Siegel. 1981. Long-therm exposure of chickens to three levels of social stress. Avian Dis. 25:312-325.

Gross W.B. and H.S. Siegel. 1983. Evaluation of the heterophil/lymphocyte ratio as a measure of stress in chickens. Avian Dis. 27: 972-979

Gross, W.B., and H.S. Siegel. 1990. Geneticenvironmental interactions and antibody response in chickens to two antigens. Avian Dis. 34:843-847.

Gross, W. B., and P. B. Siegel, 1993: General principles of stress and welfare. Pages 2134 in: Livestock, Handling and Transport (T. Grandin, ed.). CAB International, Wallingford.

Gisela, F.E. 1997. Immune System Fundtion and development in broiler. University of Arkansan Fayettville, AR 72701.

Kartasudjana, R., dan E. Suprijatna. 2006. Manajemen Ternak Unggas. Penebar Swadaya. Jakarta.

Maxwell, M.H., G.M.Robertson, M.A. Mitchell, and A.J. Carlisle. 1992: The fine structure of broiler chicken blood cells, with particular reference to basophils, after severe heat stress. Comparative Haemotology Int. 2:190-200.

Maxwell, M.H. 1993. Avian blood leucocyte responses to stress. World's Poult. Sci. J. 49:34-43.
Mashaly, M.M., G.L. Hendricks, M.A. Kalama, A.E. Gehad, A.O. Abbas and P.H. Patterson. 2004. Effect of heat stress on production parameters and immune responses of commercial laying hens. Poult. Sci. 83: 889-894.

Mills, L.J., M.A. Mitchell and M. Mahon, 1999. Comparison of thermoregulatory ability in fast and slow growing strains of turkey during acute heat stress. Br. Poult. Sci., 40: 51-2.

Naseem, M,T., S. Naseem, M. Younus, I.C.H. Zafar, G.H. Aamir, A. Asim and S. Akhter. 2005. Effect of potassium chloride and sodium bicarbonate supplementation on thermotolerance of broilers exposed to heat stress. Int. J. Poult. Sci. 4: 891-895.

Naseem, S.M., Y.B. Anwar, A. Ghafoor, A. Aslam and S. Akhter, 2005. Effect of ascorbic acid and acetylsalicylic acid supplementation on performance of broiler chicks exposed to heat stress. Int. J. Poult. Sci., 4: 900-904.

Pope, C.R. 1991. Pathology of lymphoid organs with emphasis on immunosuppression. Vet. Immunol. Immunopathol. 30:31-44.

Puvadolpirod, S., and J.P. Thaxton. 2000. Model of physiological stress in chickens 3 . Temporal pattern of respons. Poult. Sci. 79:377-382.

Scott, T.R., E.A. Dunnington, and P.B. Siegel. 1994. Brucella abortus antibody response of white leghorn chickens selected for high and low antibody responsiveness to sheep erythrocytes. Poult. Sci. 73:346-349.

Sunarti, D., 2004. Pencahayaan Sebagai Upaya Pencegahan Cekaman Pada Unggas Tropis Berwawasan Animal Welfare. Pidato Pengukuhan Peresmian Penerimaan Jabatan Guru Besar dalam Ilmu Ternak Unggas pada Fakultas Peternakan Universitas Diponegoro. Diponegoro University Press. Semarang

Scope, A.T., C. Filip, C. Gabler and F. Resch. 2001. The influence of stress from transport and handling on hematologic and clinical chemistry blood parameters of racing pigeons (Columba livia domestica). Avian Dis. 46: 224-229.

Squires, E.J. 2003. Applied Animal Endocrinology. CABI Publishing Wallingford, Oxford, UK. 